Guntis Zemitis, Dr. hist.

Institute of Latvian History at the University of Latvia, Latvia

\title{
ABOLITION OF SERFDOM IN THE BALTICS - A DEMAND DICTATED BY THE MODERN WORLD
}

\begin{abstract}
Summary
The abolition of serfdom in the Baltics is evaluated rather controversially by scholars of the history of Latvia and the history of law. Previously, historians mostly concentrated on the outcome of the abolition of serfdom, highlighting the fact that the peasants, as they acquired personal freedom (becoming vogelfrei), lost their lands, which remained the property of the nobility.

Until now, the causes of the abolition of serfdom have seldom been the focus of attention. Why did the tzar agree to abolish it earlier in the three Baltic provinces/governorates (1816 in Estonia, 1817 in Courland, 1819 in Livonia)? The answer to this question is crucial because it concerns not only the abolition of serfdom, but also the evaluation of the Baltic German aristocracy as a whole. It is also a question about the extent to which the Baltics remained integrated in the Western European (especially German) cultural, legal and economic space, even while being a part of the Russian Empire.
\end{abstract}

Keywords: Russian Empire, Baltic provinces/governorates, abolition of serfdom, Enlightenment

\section{Introduction}

The abolition of serfdom in the Baltic provinces of the Russian Empire (German: Ostseegouvernements, Russian: Остзе́йские губе́рнии, Прибалтийские губе́рнии) in the early $19^{\text {th }}$ century is one of those events in the Latvian history that are evaluated rather controversially - both positively and negatively. This refers to the attitudes towards the event, but the circumstances leading to it have not yet been discussed sufficiently.

The aim of this research is to assess the different views held by various schools of historical thought about the causes that led to abolishing serfdom in the Baltic provinces four decades earlier than in the rest of the Russian Empire, as well as to define the limitations set by the time, social group, political and ideological beliefs, and to draw conclusions about the factors that influenced the decision of Alexander I (1777-1825). On the basis of these conclusions, opinions concerning the Baltic nobility are also evaluated.

The historical method has been employed in this research. This method allows facts of the past to be considered from a present-day viewpoint. It does not claim an absolute objectivity, but helps to follow the arguments proposed during various historical periods and to evaluate their advantages and disadvantages in the context of today. 
When proclaiming the emancipation of serfs in January of 1820 , Peter Wilhelm von Buxhoeveden (1787-1841), land marshal of Saaremaa, said: "This is what [the tzar] Alexander wanted, and what the Zeitgeist wanted"1. This quote, rather illustrative of its epoch, contains the essence of the issue. Indeed, the tzar of Russia, Alexander I, wanted the abolition of serfdom, but the reasons why he wanted it are not obvious. Was it the way it is depicted in the painting "February 19, 1819" by Johann Leberecht-Eggink - where the philanthropist tzar is handing the emancipation document to the kind-hearted nobility, who will later pass it over to the astonished and overjoyed people? The truth seems to be more complicated.

The other side of the question refers to the concept of Zeitgeist. Was the event caused by the ideas of the Enlightenment, the theory of "natural rights", and the triumph of humanist thought - or by the increasing fears felt by the tzar and the nobility? Was it a necessity dictated by the circumstances?

\section{The most widespread views in Latvian historiography about the causes of the abolition of serfdom}

As already noted, the historiography of Latvia presents a range of different views about this event. Baltic German historians described the abolition of serfdom as a humanitarian act from which the whole of society benefitted ${ }^{2}$. Still, the Baltic German historiography tended to ignore the role of the peasantry.

Quite the opposite view was held in Soviet historiography, particularly by the historian Jānis Zutis ${ }^{3}$. On the basis of the methodology of Marxism-Leninism, the role of individuals was neglected, especially those belonging to the nobility. Soviet historiography analysed everything from the aspect of the class struggle, depicting the nobility as reactionary and only seeking to gain maximum benefit from the peasants' labour ${ }^{4}$.

Švābe A. Latvijas vēsture 1800-1914 [History of Latvia 1800-1914]. Uppsala: Daugava, 1958, p. 114.

2 Rennenkampf G. von. Bemerkungen über die Leibeigenschaft in Livland und ihre Aufhebung [Notes about Serfdom and Its Abolition in Livonia]. Kopenhagen: Thielische Buchdruckerei, 1818; Himmelsstiern, von S. Zur Geschichte der Bauernfreiheit in Livland [On the History of Peasant Freedom in Livonia]. Riga: Nicolai Hummel's Buchhandlung, 1878; Seraphim E. Im neuen Jahrhundert. Baltische Rückblicke und Ausblicke von Dr. Ernst Seraphim [In the New Century. Baltic Retrospects and Aspects by Dr. Ernst Seraphim]. Riga, 1902; Sievers J. Zur Geschichte der Bauernfreiheit in Livland [On the History of Peasant Freedom in Livonia]. Riga: Druck von Müller, 1878 , etc.

3 Zutis J. Vidzemes un Kurzemes zemnieku likumi 19. gs. sākumā (1804-1819) [Peasant Laws in Vidzeme and Kurzeme in Early 19 ${ }^{\text {th }}$ Century (1804-1819)]. Riga: Latvijas Valsts izdevnieciba, 1954; Zutis J. Vidzemes un Kurzemes zemnieku brīvlaišana 19. gs. 20. gados [Liberation of Vidzeme and Kurzeme Peasants in the 1820s]. In: Apcerējumi par Latvijas PSR vēsturi [Essays on the History of Latvian SSR]. Riga, 1956.

4 Latvijas PRS vēsture [History of Latvian SSR]. J. Zutis (ed.), Vol. I, No vissenākajiem laikiem līdz 1860. gadam [From the Ancient Times to 1860]. Rìga: Latvijas PSR Zinātnu akadēmija, 1953, pp. $310-401$. 
The most objective evaluation of the abolition of serfdom has so far been given during the period of the Republic of Latvia - in the works of professor Arveds Švābe, Margers Stepermanis ${ }^{5}$, and, after the renewal of independence, in the works of legal historian Jānis Lazdin̦š .

Historiographic literature most often gives the following factors as the reasons that led to the abolition of serfdom in the Baltics:

The wish of Alexander I;

The goodwill of the nobility;

The wish of the nobility to obtain the peasants' land;

Safety concerns (fear of peasant revolts, especially in the first stages of

the reforms);

The ideas of the Enlightenment;

The development of the market economy.

The important role of Alexander I, namely, his wish, was already noted by Arveds Švābe. He pointed out the fact that Alexander I in his youth had become acquainted with ideas of liberalism, and wanted to demonstrate to Europe that he (regarding himself as Europe's political leader after the defeat of Napoleon) was not afraid to implement French ideas of liberty.

Arveds Švābe wrote: "The part supported by the tzar is the fruit of the French Revolution. The part supported by the nobility is the old privileges dating back to the time of Sigismund Augustus" about the emancipation of the Baltic peasants and the corresponding bills were made by the Landtags of the provinces, it was no secret that the main incentive came from St. Petersburg."

Indeed, the Baltic nobility usually protested against any reforms that might reduce their privileges. Thus, baron W. F. von Ungern-Sternberg claimed in 1803 that

5 Stepermanis M. Pirmās cinnas par dzimtbūšanas atcelšanu Vidzemē 1750-1764 [The First Struggle for the Abolition of Serfdom in Vidzeme 1750-1764]. In: Izglitïbas Ministrijas Mēnešraksts [Monthly of the Ministry of Education]. 1931, No. 10 and 11; Stepermanis M. J. G. Eizens un viña darbi par dzimtbušanas atcelšanu Vidzemē [J. G. Eisen and His Works about the Abolition of Serfdom in Vidzeme]. Riga: Latvijas vēstures skolotāju biedrība, 1934.

6 Lazdiňš J. Baltijas zemnieku privāttiesības (XIX gs.) [Private Laws of Baltic Peasants (19 $9^{\text {th }}$ Century)]. Rìga: Biznesa augstskola Turība, 2000; Lazdinšs J. Abolition of Serfdom and Organisation of Civil Parish Communities. In: Latvia and Latvians. Riga: Latvian Academy of Sciences, 2018, pp. 312-346.

7 Švābe A. Latviešu zemnieku brīvlaišanas politiskās un tiesiskās idejas [The Political and Legal Ideas of Latvian Peasant Liberation]. In: Pagātne un tagadne II. Latvijas Vēstures skolotāju biedrības rakstu krājums [Past and Present II. Journal of Latvian History Teachers Association]. [Ed. by] L. Adamoviča un N. Vīksniņa redakcijā. Rīga: Latvijas vēstures skolotāju biedrība, 1938, pp. 131-132.

8 Ibid., p. 112. 
serfdom should be preserved by any means, including artillery, in order to suppress rebellious thoughts?.

The dominant view in Soviet historiography was that the abolition of serfdom served the interests of the nobility. It was concluded that the existence of serfdom did not allow them to adapt to the fluctuations of the market economy and, most importantly, could not solve the new economic tasks - to raise the productivity of peasant labour to a level that would satisfy the growing demands of the nobility.

Soviet historians referred to Karl Marx and pointed out that the question was not about getting the maximum amount of products from a slave or serf, but about "producing surplus value" 10 .

Similarly, law historian Voldemārs Kalniņš wrote: "Abolition of serfdom in the Baltic provinces served the interests of the nobles themselves", nevertheless admitting that "it had a progressive effect - it led to the collapse of the corvée labour system"11. Since Alexander I, fearing peasant rebellions, did not want to increase their exploitation, the nobility tried to grab peasant lands in order to increase their own properties. It became a particularly hot issue after the Napoleonic wars. The liberation of peasants without their land - in other words, giving the land of the peasants over to the nobles - completely satisfied the interests of the nobility ${ }^{12}$.

If we were to follow this logic, we might say that the supporters of Enlightenment ideas, such as Garlieb Merkel and Johann Georg Eisen von Schwarzenberg - were actually serving the interests of the nobility.

Another factor that might have had a decisive role in abolishing serfdom was the safety concern. After the French Revolution one could not ignore this factor.

As early as in 1796, Garlieb Merkel in his work Die Letten: wrote: "The people are no longer a blind dog that will retreat to its kennel when beaten. It is a tiger silently gnawing at its chain and waiting for the moment to break it and to wash off its shame with blood"13.

After the involvement of Russia in European politics following the French Revolution, the issue of internal security became particularly essential. Thus, Alexander I was forced to see to the internal stability of his country, especially

9 Ungern-Sternberg von W. F. Ist die von einigen des Adels projektierte Einführung der Freiheit unter dem Bauernstande / Bauernzustande in Livland dem Staatsrecht Russlands konform: Eine Abhandlung den Landtag in Livland von 1803 betreffend.

10 Markss K. Kapitāls [The Capital]. Vol. I, p. 223; Latvijas PSR vēsture [History of Latvian SSR]. Vol. I. No vissenākajiem laikiem līdz 1860. gadam. J. Zutis (ed.), Rīga, 1953, pp. 350-351.

11 Kalninš V. Latvijas PSR valsts un tiesību vēsture [State and Legal History of Latvian SSR]. Rīga: Zvaigzne, 1972, p. 254.

12 Latvijas PSR vēsture. Saīsinātais kurss [History of Latvian SSR. An Abridged Course]. Akad. K. Strazdiṇa red. Rīga: Latvijas PSR Zinātṇu akadēmijas izdevniecība, 1956, p. 115; Latvijas PSR vēsture. Saīsinātais kurss. Otrais, pārstrādātais un papildinātais izdevums [History of Latvian SSR. An Abridged Course. New and Supplemented Edition]. Drīzulis A. (ed.), Rīga: Zinātne, 1967, p. 109.

13 Merkel G. Die Letten, vorzüglich in Liefland, am Ende des philosophischen Jahrhunderts. Ein Beitrag zur Völker- und Menschenkunde [The Latvians, Mostly in Livonia, in the End of the Century of Philosophy. A Contribution to the Study of Nations and People]. Leipzig: bey Heinrich Gräff, 1797, S. 226. 
near the borders ${ }^{14}$. He paid special attention to the province of Estonia, and in 1808 appointed as its governor general his brother-in-law, prince George of Oldenburg. The war with Sweden over Finland was not yet over.

There had already been several peasant uprisings in the governorates of Livonia and Estonia - for instance, in 1771 they took place in the parishes of Alūksne, Gulbene etc., and had to be suppressed with the help of the army. The largest rebellion took place in Kauguri in 1802. As the result of conflict with the army, four peasants were killed in the action and ten died afterwards. ${ }^{15}$ The historians P. Bērziñ̌s and A. Švābe have pointed out that the rebellious peasants knew about the recent revolution in France ${ }^{16}$.

In the summer and autumn of 1805 , peasant uprisings were taking place in the district of Tartu and elsewhere in Estonia. The tzar urged the nobility to start reforms. Consequently, in 1804 the peasant laws of Livonia were elaborated in order to improve their situation. A peasant farm-owner still was not allowed to leave his landlord, but the landlord had no rights to seize the peasant's land.

During 1805-1807, Russia was involved in warfare in Europe, and the tzar's dialogue with the nobility was temporarily interrupted. It resumed in July 1809 in Estonia. In 1811, the Landtag of Estonia decided to grant personal freedom to peasants, but to keep their lands in the ownership of the landlords. The tzar approved this project and ordered a commission to prepare a bill. The Landtag adopted it in 1812, but Alexander I implemented it only in 1816, after the Napoleonic wars.

Undeniably, the Enlightenment reached the Baltics sooner than the other governorates of the Russian Empire. Johann Georg Eisen von Schwarzenberg and especially Garlieb Merkel, as well as Georg Friedrich Parrot (1767-1852; a Frenchman born in Württemberg, later to become the first rector of the University of Tartu), in 1802 submitted to the tzar a work entitled Considérations sur la servitude. In this document, G. Parrot referred to the theory of natural rights, whereby slavery contradicts human nature, and the most abhorrent form of trade is the purchase of human beings.

\section{The ideas of the Enlightenment as a stimulus to the market economy}

The role of the natural rights defined by the Enlightenment has also been pointed out by historians of law. It was also emphasized by Arveds Švābe. In his work "History of Latvia 1800-1914" (published abroad in 1958), he said: "The philosophy of rationalism and the doctrine of natural rights was the ideological workshop for forging the spiritual weapons meant to destroy the old regime, i.e.

${ }^{14}$ Latvija 19. gadsimtā. Vēstures apceres [Latvia in the $19^{\text {th }}$ Century. Essays on History]. Bērziņš J. (ed.), Rìga: Latvijas vēstures institūta apgāds, 2000, p. 27.

15 Bērzinš P. Zemnieku nemieri Kauguros 1802. g. [Peasant Uprising in Kauguri in 1802]. Latvijas Vēstures Institūta Žurnāls [Journal of Latvian Institute of History], No. 4, 1937, pp. 540-541.

16 Bērziņš P. Zemnieku nemieri Kauguros 1802. g. [Peasant Uprising in Kauguri in 1802], p. 551; Švābe A. Latvijas vēsture 1800-1914 [History of Latvia 1800-1914], p. 69. 
feudalism, and to build a civil society. On the basis of natural rights, the abolition of serfdom in the Baltics was demanded already in the $18^{\text {th }}$ century by Eisen, Merkel and other enlighteners"17.

It has been formulated even more convincingly by Jānis Lazdinšs: "The abolition of serfdom was not only a victory of natural rights in the struggle for human freedom"18.

Last but not the least - the abolition of serfdom was a necessary precondition for the transition to a market economy. In 1764, Johann Georg Eisen von Schwarzenberg's book Eines Liefländischen Patrioten Beschreibung der Leibeigenschaft, wie solch in Liefland über die Bauern eingeführt ist ${ }^{19}$ was published in St. Petersburg. The author criticized serfdom not so much from the ethical as from the economic aspect. In 1795, Georg Parrot wrote a booklet Über eine mögliche öconomische Gesellschaft in und für Livland ${ }^{20}$, where he pointed out the agricultural backwardness of the region in comparison to Germany and France ${ }^{21}$.

Estonian historian Seppo Zetterberg has pointed out that, even though the intellectuals who criticized the situation of the peasants were mostly clergymen, they rarely spoke from an ethical or moral aspect, and usually supported the need to improve peasant life for economic reason ${ }^{22}$. Jānis Lazdinš has also stressed that the abolition of serfdom was a necessary precondition for the transition to a new kind of economic relations - capitalism ${ }^{23}$. Since the epoch of Solon, a citizen's freedom is considered as a precondition for the prosperity of the state.

The situation could change after the Napoleonic wars. Napoleon pessimistically predicted that the battle of Waterloo in 1815 was a blow not only to France but also to liberalism. Even though after the Napoleonic wars there was a certain reaction in Europe, a complete return to the old order was no longer possible. When the wars were over, there appeared a chance to dispose of agricultural products, thus causing the growth of agricultural intensity.

17 Švābe A. Latvijas vēsture 1800-1914 [History of Latvia 1800-1914], p. 122.

18 Lazdiņš J. Dzimtbūšanas atcelšana, pagasta sabiedrïbas organizācija un nacionāli valstiskas domāšanas pirmsākumi [Abolition of Serfdom, Local Social Organizations, and the Beginnings of National and State-oriented Thinking]. In: Latvija un latvieši. II sēj. [Latvia and Latvians. Vol. II]. Rìga: Latvijas Zinātñu akadēmija, 2013, p. 182; Lazdinš̌ J. Abolition of Serfdom and Organisation of Civil Parish Communities, p. 345.

19 Eisen J. G. Eines Liefländischen Patrioten Beschreibung der Leibeigenschaft, wie solch in Liefland über die Bauern eingeführt ist. In: Sammlung Russischer Geschichte [A Patriot's Description of Serfdom and its Establishment over the Peasants in Livonia]. 9. S. 491-527. Available at: https:// dspace.ut.ee/bitstream/handle/10062/6489/eisen1.pdf?sequence $=1$ \&isAllowed=y $\quad$ last viewed November 1, 2019].

20 Parrot G. Über eine mögliche öconomische Gesellschaft in und für Livland [On the Possible Economic Society in Livonia]. Riga, 1795.

21 Švābe A. Latvijas vēsture 1800-1914 [History of Latvia 1800-1914], p. 69.

22 Zeterbergs. Igaunijas vēsture [History of Estonia]. Rīga: Latvijas Mediji, 2018, pp. 202, 203.

23 Lazdiņš J. Dzimtbūšanas atcelšana, pagasta sabiedrības organizācija un nacionāli valstiskas domāšanas pirmsākumi [Abolition of Serfdom, Local Social Organizations, and the Beginnings of National and State-oriented Thinking], p. 182. 
The existence of serfdom did not encourage the peasants to work effectively, thus harming both the peasants and landlords ${ }^{24}$. The abolition of serfdom and liberation of the peasants, meanwhile allowing them to keep their land, corresponded to the natural rights formula "to each his own" (suum cuique).

\section{Conclusions}

Following the age of Enlightenment and the French revolution, a new situation had emerged in Europe. A return to the old feudal system would condemn a state to backwardness, which would be harmful both to the peasants and the nobility.

The educated part of society in Russia, including the emperor Alexander I, understood this. However, in the situation of Russia one had to take into account the opposition of the nobility. It is noteworthy that the support for the reforms grew during the period when the veterans of the Napoleonic wars returned to Russia after having seen Western Europe.

The Baltics became a testing ground for further reforms in Russia, because here the ideas of the Enlightenment had spread earlier and had been more widely supported. The Baltic nobility was readier for change than the Russian nobility. Neither can the role of the peasant revolts be ignored.

\section{Acknowledgements}

The article was prepared within the framework of the project "Interaction between the individual, the society and the state in process of the history of Latvia: conflicting values and formation of shared values during historical turning points" (VPP-IZM-2018/1-0018).

\section{BIBLIOGRAPHY}

\section{Literature}

1. Bērziņš P. Zemnieku nemieri Kauguros 1802. g. [Peasant Uprising in Kauguri in 1802]. In: Latvijas Vēstures Institūta Žurnāls, No. 4, 1937, pp. 540, 541.

2. Eisen J. G. Eines Liefländischen Patrioten Beschreibung der Leibeigenschaft, wie solch in Liefland über die Bauern eingeführt ist. In: Sammlung Russischer Geschichte. 9. S. 491-527. Available at: https://dspace.ut.ee/bitstream/handle/10062/6489/eisen1.pdf? sequence $=1$ \&isAllowed $=y$ [last viewed November 1, 2019].

3. Himmelsstiern von S. Zur Geschichte der Bauernfreiheit in Livland. Riga: Nicolai Hummel's Buchhandlung, 1878.

4. Kalniņš V. Latvijas PSR valsts un tiesību vesture [State and Legal History of Latvian SSR]. Riga: Zvaigzne, 1972, p. 254.

5. Lazdiņš J. Baltijas zemnieku privāttiesības (XIX gs.) [Private Laws of Baltic Peasants (19 $9^{\text {th }}$ Century) $]$. Riga: Biznesa augstskola Turìba, 2000.

6. Lazdiņš J. Dzimtbūšanas atcelšana, pagasta sabiedrības organizācija un nacionāli valstiskas domāšanas pirmsākumi [Abolition of Serfdom, Local Social Organizations, and the Beginnings

${ }^{24}$ Zeterbergs S. Igaunijas vēsture [History of Estonia]. Rīga: Latvijas Mediji, 2018, p. 200. 
of National and State-oriented Thinking]. In: Latvija un latvieši. Vol. II. Rīga: Latvijas Zinātṇu akadēmija, 2013, pp. 173-196.

7. Lazdiņš J. Abolition of Serfdom and Organisation of Civil Parish Communities. In: Latvia and Latvians. Riga: Latvian Academy of Sciences, 2018, pp. 312-346.

8. Latvija 19. gadsimtā. Vēstures apceres [Latvia in the $19^{\text {th }}$ Century. Essays on History]. Bērziņš J. (ed.), Rīga: Latvijas vēstures institūta apgāds, 2000.

9. Latvijas PRS vēsture [History of Latvian SSR]. Zutis J. (ed.), Vol. I, No vissenākajiem laikiem līdz 1860. gadam [From Ancient Times to 1860]. Rịga: Latvijas PSR Zinātnuu akadēmija, 1953.

10. Latvijas PSR vēsture. Saīsinātais kurss [History of Latvian SSR. An Abridged Course]. Strazdiņ̌̌ K. (ed.), Rīga: Latvijas PSR Zinātṇu Akadēmijas izdevniecība, 1956, p. 115.

11. Latvijas PSR vēsture. Saīsinātais kurss. Otrais, pārstrādātais un papildinātais izdevums [History of Latvian SSR. An Abridged Course. New and Supplemented Edition]. Drīzulis A. (ed.), Rìga: Zinātne, 1967.

12. Markss K. Kapitāls [The Capital]. Politiskās ekonomikas kritika. Rīga: Liesma, 1975, Vol. I = Marx K. Das Kapital. Kritik der politischen Ökonomie. 1867.

13. Merkel G. Die Letten, vorzüglich in Liefland, am Ende des philosophischen Jahrhunderts. Ein Beitrag zur Völker- und Menschenkunde. Leipzig: bey Heinrich Gräff, 1797.

14. Parrot G. Über eine mögliche öconomische Gesellschaft in und für Livland. Riga, 1795.

15. Rennenkampf G. von. Bemerkungen über die Leibeigenschaft in Livland und ihre Aufhebung. Kopenhagen: Thielische Buchdruckerei, 1918.

16. Seraphim E. Im neuen Jahrhundert. Baltische Rückblicke und Ausblicke von Dr. Ernst Seraphim. Riga, 1902.

17. Sievers J. Zur Geschichte der Bauernfreiheit in Livland. Riga: Druck von Müller, 1878.

18. Stepermanis M. Pirmās cinnas par dzimtbūšanas atcelšanu Vidzemē 1750-1764 [The First Struggle for the Abolition of Serfdom in Vidzeme 1750-1764]. Izglitibas Ministrijas Mènešraksts [Monthly of the Ministry of Education], No. 10, 11, 1931.

19. Stepermanis M. J. G. Eizens un viņa darbi par dzimtbūšanas atcelšanu Vidzemēe [J. G. Eisen and His Works about the Abolition of Serfdom in Vidzeme]. Rìga: Latvijas vēstures skolotāju biedrība, 1934.

20. Švābe A. Latviešu zemnieku brīvlaišanas politiskās un tiesiskās idejas [The Political and Legal Ideas of Latvian Peasant Liberation]. In: Pagātne un tagadne II. Latvijas Vēstures skolotāju biedrības rakstu krājums [Past and Present II. Journal of Latvian History Teachers Association]. Adamovičs L., Vīksniņš N. (eds.), Rīga: Latvijas vēstures skolotāju biedrība, 1938.

21. Švābe A. Latvijas vēsture 1800-1914 [History of Latvia 1800-1914]. Uppsala: Daugava, 1958.

22. Ungern-Sternberg von W. F. Ist die von einigen des Adels projektierte Einführung der Freiheit unter dem Bauerstende in Livland dem Staatsrecht Russlands konform Eine Abhandlung den Landtag in Livland von 1803 betreffend.

23. Zeterbergs S. Igaunijas vēsture [History of Estonia]. Rīga: Latvijas Mediji, $2018=$ Zetterberg S. Uusi Viron Historia, 2018.

24. Zutis J. Vidzemes un Kurzemes zemnieku likumi 19. gs. sākumā (1804-1819) [Peasant Laws in Vidzeme and Kurzeme in the Early $19^{\text {th }}$ Century (1804-1819)]. Riga: Latvijas Valsts izdevniecība, 1954.

25. Zutis J. Vidzemes un Kurzemes zemnieku brīvlaišana 19. gs. 20. gados [Liberation of Vidzeme and Kurzeme Peasants in the 1820s]. In: Apcerējumi par Latvijas PSR vēsturi [Essays on the History of Latvian SSR]. Riga, 1956. 